\title{
OPERATIONAL ANALYSIS OF CONTAINER TRUCK ON CONGESTION AT TANJUNG PRIOK PORT
}

\author{
Tedy Herdian ${ }^{1}$, Tridoyo Kusumastanto ${ }^{2}$, Bagus Sartono ${ }^{3}$, Hafida \\ Fahmiasari $^{4}$ \\ 1. IPB, Bogor Agricultural University, 2. IPB, Bogor Agricultural University \\ 3. IPB, Bogor Agricultural University, 4. Maritime Transport, World Bank \\ Group \\ Corresponding author: tedyher@gmail.com
}

\begin{abstract}
The operation of container trucks at Tanjung Priok Port, which includes the movement pattern and empty trip has the potential to congestion at the port. Data analysis was conducted with the population of the terminal operating system (TOS) in Koja Container Terminal (TPK Koja), as much as 1,115,344 row data in two years. The data were obtained from the results of in-depth interviews with the heads of trucking entrepreneurs associations and management. There are 17,143 container trucks operated to pick up \& deliver 578,963 containers in 2015. The pattern of container truck carrying one container in a single trip is more than $80 \%$. The inbound and outbound empty trips of container trucks in 2016 at the Port of Tanjung Priok are 1,522,727 and 1,908,227. The addition of Tanjung Priok Port capacity, the development of toll road access and new rail mode in the port do not necessarily reduce congestion at the port. A plan of having a barge system requires expensive investment but feared will not reduce congestion significantly. Port stakeholders, both government and employers need to collaborate to build a reliable container truck transportation system by the best practice and the uniqueness of Tanjung Priok Port. It is time for stakeholders at the port to see the congestion problem from the operational perspective of the container truck. The port will still be burdened by congestion if the container truck operation is not considered determinedly.
\end{abstract}

Keywords: Congestion, Container Terminal, Port, Empty Trip, Movement Pattern, Container Truck.

\section{Introduction}

Congestion of container trucks at the terminal is an unforeseen phenomenon worldwide. It happens because of the abundant of trucks operating in the terminal at that time (Dekker R et al., 2012), unanticipated Turnaround time (TRT) of the truck by terminal operators (Kiani M et al. 2009), low utilization of assets vehicles (container trucks) where there are empty slots contained in the container truck chassis (Islam $\mathrm{S}$ and Olsen $\mathrm{T}$. 2014) and the underutilized truck journey (Islam S. et al., 2013), Port capacity has not increased enough to adjust the volume growth. Thus, it leads to 
congestion around the port (Maloni MJ, Jackson EC. 2007). Many countries have limited tools and data to know the number of container trucks (Giuliano G et al. 2006).

Indonesia is an archipelagic country with over than 17,500 islands. Inter-island trade there uses several modes of transportation. The attention given to the planning of the multimodal transportation system is relatively small, especially at the national level (Russ BF et al. 2005), The role of multimodal transport in Indonesia is not yet optimal (Irpan T et al. 2016). The role of the transport sector in Indonesia plays a very important role on the livelihood of many people, both for economic interests and non-economic (Kadarisman $\mathrm{M}$ et al. 2016). Tanjung Priok Port as the main port in export and import services in Indonesia still faces the problem of congestion of container trucks entering or exiting the port area. The effect can be spread to the West: Jl. RE Martadinata, South: Jl. Yos Sudarso and East: Jl. Jampea to Cakung-Cilincing.

The container throughput of Tanjung Priok Port consists of four terminals: Jakarta International Container Terminal (PT. JICT), Koja Container Terminal (KSO TPK Koja), New Port Container Terminal 1 (PT NPCT 1) are the container terminal specializing in international service and Tanjung Priok Port (PT PTP) is a container terminal serving international and domestic. The total container of Tanjung Priok at the end of 2015 is $5,200,122$ TEUs or 3,780,064 Boxes. The market share based on the boxes: PT.PTP $43.1 \%$, PT JICT $39.7 \%$ and KSO TPK Koja 17.2\%. While the number of containers in 2016 as much as 5,518,729 TEUs or 4,035,126 Boxes. Its market share based on the boxes: PT. PTP 48.5\%, PT JICT 36.4\%, KSO TPK Koja 13.9\%, and PT NPCT 1 as much as 1.2\%. Indonesia's export and import tend to deficit overall (Lesmini L, Purwanto B. 2016)

Congestion impacts inefficiency in the operation process (Danloup $\mathrm{N}$ et al., 2015), the delay in the truck terminal which will result in additional cost to the goods to the customer. Congestion harms not only the owners of goods and operations but also the environment, emissions from transport activities have resulted in global climate change and damaging the quality of water and 
human health in regional and urban areas (Wheeler NM 2010). To reduce the dominance of container trucks, some developing countries try to optimize via rail mode (Juan AA et al., 2013). The need for structured transportation management and performance can be more efficient and sustainable by reducing the negative impact of emissions (Kopfer HW et al., 2013). The quality of human resources directly affects the smooth delivery of goods and logistics costs (Nugraha $Y$ et al. 2016)

Poor infrastructure and inefficient supervisory institutions are the main causes of delays (Rafi S, Purwanto B. 2016). The Government's efforts through the Coordinating Ministry for Maritime Affairs and the Ministry of Transportation were carried out by activating the railway line in Tanjung Priok Port. The effort from PT. Pelabuhan Indonesia II, which proposes to carry containers through the river route (Cikarang-Bekasi-Laut) by barge, is needed as a solution to reduce queuing of container trucks at Tanjung Priok Port.

Although trucks are considered of being the culprit of traffic jams and pollution, the truck fleet remains a prima donna in container transport. Some of the advantages of using the truck fleet mentioned in the Blueprint of National Logistics System (SISLOGNAS): it can serve door-to-door services due to high accessibility and flexibility and excellent in-transit visibility. The benefits mentioned above are the characteristic of trucking that causes this mode to be selected for the delivery of finished goods

The capacity of Tanjung Priok Port continues to increase with the construction of a new container terminal. On the other hand, the government has completed a tollway to the port this year. The project should be done to anticipate the increase in trading volume and facilitate the flow of goods through containers. But this will not necessarily break down the existing congestion problem; it could potentially add to congestion. The problem is due to the increase in trading volume using containers, like the increase of truck fleets as the primary mode of transportation of containers.

This research was conducted to analyze the pattern of container and the empty trip container truck. With the support of population data for two years, 
it is expected that the port stakeholders can have a similar perspective in looking at the problem of congestion of container trucks. In the end, this angle will be constructive in finding the right solution for reducing congestion of container trucks at Tanjung Priok Port.

\section{The Operational Rules of Container Truck in Indonesia}

A container carrier vehicle on the road is only permitted to transport one container according to the length of the embedded cart. It is not allowed to carry two containers simultaneously by using one motor vehicle carrying container on the road by Regulation of the Minister of Transportation No. 14 of 2007 on Container Transport Vehicles.

As of July 1st, 2016, the Tanjung Priok Port Authority applied the verifiable weight requirements of verified containers as stipulated in the 1974 SOLAS Amendment Chapter VI Article 2 on Verified Gross Mass of Container (VGM) governing the need for weighing of export destination containers. The regulation is stipulated in Regulation of Director General of Sea Transportation Number HK.103 / 2/4 / DJPL-16 concerning Verified Gross Mass of Container (VGM), and its amendment, namely Regulation of Director General of Sea Transportation Number HK.103 / 2/5 / DJPL- 16. Subsequently, a Letter of the Head of Tanjung Priok Harbormaster Office and the Head of Tanjung Priok Port Authority Office Number UM 003/17/8 / OP TPK-16 and UM 003/25/7 / SYB TPK-16 dated June 29 on Weighing Weight Verified Gross Mass of Container (VGM) at Tanjung Priok Port is created.

\section{Method}

The research is conducted in KSO TPK Koja, this area is part of Tanjung Priok Port. KSO TPK Koja has implemented gate automation system where all data of container truck transaction is stored digitally in the form of a very complex database.

The raw data in table form with column details has these parameters: no truck (TN), no container (CI), container status (CS) consist of export (Exp) and import (Imp), container weight (CW), truck in (TI), truck out (TO), date 
of incoming truck terminal/date in (DI), name of trucking company (TCN). The details of the raw terminal data being analyzed are shown in Table 1.

\section{The technique of data collection}

The data collection technique is a census or population from January 2015 to December 2016. The in-depth interview is also conducted to complete the analysis, the interviewees are the Chairman of the Indonesian Container Truck Entrepreneurs Association (APTRINDO) and several companies that own a large fleet of container trucks.

\section{The Data Analysis}

A series of analytical processes are made in the form of data processing algorithms and displayed in the data analysis flowchart in Figure 2 (Appendix). The following series of processes are performed to create the data analysis divided into two phases. The first phase consists of cleaning data, formatting, adding data column, sorting data. The second phase consist of selecting data, counting the number of trucks, counting the number of containers carried, counting TM-OC (truck movement only one container), counting TM-MTOC (truck movement with more than one container) and calculating the number of patterns of movement of container trucks.

Table 1. Raw data of TPK Koja on January 2015

\begin{tabular}{|c|c|c|c|c|c|c|c|c|c|}
\hline No & $\begin{array}{l}\text { Truck No } \\
\text { (TN) }\end{array}$ & $\begin{array}{c}\text { Container Id } \\
\text { (Ci) }\end{array}$ & $\begin{array}{l}\text { Stat } \\
\text { (CS) }\end{array}$ & $\begin{array}{l}\text { Feet } \\
\text { (CF) }\end{array}$ & $\begin{array}{l}\text { Weight } \\
\text { (CW) }\end{array}$ & $\begin{array}{l}\text { Truck } \\
\text { In (Ti) }\end{array}$ & $\begin{array}{l}\text { Truck } \\
\text { Out } \\
\text { (TO) }\end{array}$ & $\begin{array}{l}\text { Date } \\
\text { (DN) }\end{array}$ & $\begin{array}{l}\text { Truck } \\
\text { Company } \\
\text { (TCN) }\end{array}$ \\
\hline 1 & B9812UEK & OOLU9768770 & Imp & 40 & 6,100 & $0: 38: 05$ & $1: 47: 26$ & 1 & PT. LANCAR. \\
\hline 2 & B9480UEL & CAIU8923135 & Imp & 40 & 6,600 & $0: 38: 48$ & $1: 35: 22$ & 1 & PT. LANCAR. \\
\hline 304 & B9479VB & TGHU5022057 & Imp & 40 & 29,500 & 10:08:07 & $10: 48: 15$ & 1 & PT. ABADI. \\
\hline 305 & B9664UEJ & MSCU5021050 & Exp & 40 & 18,000 & 10:08:49 & $10: 33: 53$ & 1 & PT. PESAKA. \\
\hline 306 & B9836DI & KMTU7423255 & Imp & 20 & 23,100 & $10: 10: 44$ & $11: 10: 41$ & 1 & PT. JAYA \\
\hline 8013 & B9745RJ & TEMU3051202 & Exp & 20 & 9,740 & 20:18:04 & $21: 03: 36$ & 8 & PT. EKSPRES \\
\hline 8014 & B9291XA & CAIU9231830 & Imp & 40 & 8,400 & $20: 18: 14$ & $21: 21: 21$ & 8 & PT. DARAT \\
\hline 8015 & B9990BEH & OOLU2879196 & Imp & 20 & 25,200 & $20: 20: 01$ & $21: 58: 37$ & 8 & H TRANS \\
\hline 8016 & B9323UEJ & HJCU6224361 & Exp & 20 & 9,000 & $20: 21: 16$ & $21: 47: 52$ & 8 & PT. SIROS A. \\
\hline 27075 & B9401BYT & BMOU5406463 & Imp & 40 & 29,600 & $23: 47: 21$ & $2: 10: 17$ & 20 & КОРАВА \\
\hline 27076 & N9351US & TEMU7228066 & Imp & 40 & 30,600 & $23: 48: 53$ & $3: 38: 24$ & 20 & PT. MERPATI \\
\hline 27077 & B9603PJ & TEMU5727390 & Exp & 20 & 20,000 & $23: 49: 19$ & $0: 34: 31$ & 20 & PT. TRAN L.I. \\
\hline 33521 & B9334AB & DRYU4081600 & Exp & 40 & 25,000 & $13: 21: 34$ & $13: 43: 45$ & 24 & $\begin{array}{l}\text { PT. SENTOSA } \\
\text { A. }\end{array}$ \\
\hline 33522 & B9085XE & TRHU2952719 & Exp & 20 & 15,300 & $13: 22: 12$ & $14: 42: 11$ & 24 & KOРАВА \\
\hline 33523 & B9955UEJ & BMOU9716493 & Exp & 40 & 3,900 & $13: 22: 25$ & $14: 22: 47$ & 24 & $\begin{array}{l}\text { PT. } \\
\text { TRANSINDO }\end{array}$ \\
\hline 46462 & B9677WX & GESU3719707 & Exp & 20 & 3,500 & $23: 59: 18$ & $0: 39: 20$ & 31 & PT. BENUA \\
\hline 46463 & B9677WX & TGHU1766699 & Exp & 20 & 3,500 & $23: 59: 18$ & $0: 39: 20$ & 31 & PT. BENUA \\
\hline 46464 & B9672UO & CAXU9053535 & Imp & 40 & 30,500 & $23: 59: 41$ & $0: 21: 44$ & 31 & PT. INDAH G. \\
\hline
\end{tabular}


Table 2. Result of data analysis in Phase 1

\begin{tabular}{|c|c|c|c|c|c|c|c|c|c|c|c|c|}
\hline \multirow{2}{*}{ No } & \multirow{2}{*}{$\begin{array}{c}\text { Truck } \\
\text { No }\end{array}$} & \multirow{2}{*}{ Container Id } & \multirow[t]{2}{*}{ Stat } & \multirow[t]{2}{*}{ Fee } & \multicolumn{2}{|c|}{ Truck } & \multirow{2}{*}{$\begin{array}{l}\text { Dat } \\
\text { e }\end{array}$} & \multicolumn{2}{|c|}{ Gate } & \multirow[t]{2}{*}{ TM } & \multirow[t]{2}{*}{ DM } & \multirow[t]{2}{*}{$\begin{array}{c}\text { Time } \\
\text { Limit } \\
\end{array}$} \\
\hline & & & & & In & Out & & In & Out & & & \\
\hline 70 & A9109UA & OOLU9437895 & Exp & 40 & $2: 50: 27$ & $3: 55: 21$ & 01 & 1 & 0 & & $\mathrm{~S}$ & $\begin{array}{l}1: 00: 0 \\
0\end{array}$ \\
\hline 645 & A9299UA & MEDU1884151 & Exp & 20 & $17: 27: 36$ & $\begin{array}{l}17: 42: 3 \\
9\end{array}$ & 01 & 1 & 0 & & S & $\begin{array}{l}0: 01: 0 \\
0\end{array}$ \\
\hline 22 & B9001UEK & OOLU1868330 & Imp & 20 & $1: 19: 17$ & 2:28:56 & 01 & 0 & 1 & & CI-1 & \\
\hline 21 & B9001UEK & OOLU1451623 & Imp & 20 & $1: 19: 17$ & 2:28:57 & 01 & 0 & 1 & 0:00:01 & $\mathrm{CI}-2$ & \\
\hline 184 & B9001UEK & CAIU9163464 & Imp & 40 & 7:07:06 & $7: 33: 54$ & 01 & 0 & 1 & $0: 51: 20$ & RI & \\
\hline 443 & B9012SOK & OOLU8162812 & Exp & 40 & $13: 21: 36$ & $\begin{array}{l}13: 44: 1 \\
5\end{array}$ & 01 & 1 & 0 & & SPD-E & \\
\hline 485 & B9012SOK & OOLU7399224 & Imp & 40 & $13: 47: 32$ & $\begin{array}{l}14: 29: 1 \\
0\end{array}$ & 01 & 0 & 1 & 0:03:17 & SPD-I & \\
\hline 9989 & B9900UZ & ZIMU1190326 & Exp & 20 & $20: 36: 05$ & $\begin{array}{l}21: 00: 5 \\
3\end{array}$ & 09 & 1 & 0 & & CI-1 & \\
\hline 9990 & B9900UZ & UESU2206088 & Exp & 20 & $20: 36: 05$ & $\begin{array}{l}21: 00: 5 \\
4\end{array}$ & 09 & 1 & 0 & 0:00:00 & SPD-E & \\
\hline 10047 & B9900UZ & OOLU7751145 & Imp & 40 & $21: 02: 24$ & $\begin{array}{l}22: 01: 1 \\
4\end{array}$ & 09 & 0 & 1 & 0:01:30 & SPD-I & \\
\hline 14798 & B9068AX & CAXU6541840 & Exp & 20 & $16: 03: 12$ & $\begin{array}{l}16: 32: 4 \\
8\end{array}$ & 13 & 1 & 0 & & CI-1 & \\
\hline 14797 & B9068AX & TGHU3101780 & Exp & 20 & $16: 03: 12$ & $\begin{array}{l}16: 32: 4 \\
9\end{array}$ & 13 & 1 & 0 & 0:00:00 & SPD-E & \\
\hline 14823 & B9068AX & CRXU1554279 & Imp & 20 & $16: 33: 06$ & $\begin{array}{l}17: 06: 5 \\
3\end{array}$ & 13 & 0 & 1 & 0:00:17 & SPD-I & \\
\hline 14824 & B9068AX & TEMU4257409 & Imp & 20 & $16: 33: 06$ & $\begin{array}{l}17: 06: 5 \\
3 \\
\end{array}$ & 13 & 0 & 1 & 0:00:00 & $\mathrm{CI}-2$ & \\
\hline 22234 & B9652HL & TCKU1612573 & Exp & 20 & $9: 53: 52$ & $\begin{array}{l}10: 15: 3 \\
5\end{array}$ & 17 & 1 & 0 & & CE-1 & \\
\hline 22235 & B9652HL & CXDU1607242 & Exp & 20 & $9: 53: 52$ & $\begin{array}{l}10: 15: 3 \\
9\end{array}$ & 17 & 1 & 0 & 0:00:00 & CE- 2 & \\
\hline 23051 & B9652HL & SEGU1572000 & Exp & 20 & $17: 47: 25$ & $\begin{array}{l}19: 09: 3 \\
1\end{array}$ & 17 & 1 & 0 & $7: 53: 33$ & CE-1 & \\
\hline 23050 & B9652HL & SEGU1651840 & Exp & 20 & $17: 47: 25$ & $\begin{array}{l}19: 09: 3 \\
2\end{array}$ & 17 & 1 & 0 & 0:00:00 & CE- 2 & \\
\hline 29919 & B9108FEH & CAIU3492971 & Exp & 20 & $9: 26: 02$ & $9: 45: 01$ & 22 & 1 & 0 & & SPD-E & \\
\hline 29941 & B9108FEH & GLDU2968614 & Imp & 20 & $9: 46: 33$ & $\begin{array}{l}11: 41: 3 \\
3\end{array}$ & 22 & 0 & 1 & 0:01:32 & SPD-I & \\
\hline 43411 & H1902ES & PONU2914361 & Exp & 20 & 13:59:59 & $\begin{array}{l}14: 21: 2 \\
4\end{array}$ & 30 & 1 & 0 & & CE-1 & \\
\hline 43412 & H1902ES & MWCU5623159 & Exp & 20 & 13:59:59 & $\begin{array}{l}14: 21: 2 \\
5\end{array}$ & 30 & 1 & 0 & 0:00:00 & CE- 2 & \\
\hline 45615 & N8062US & HJCU1512534 & Exp & 40 & $13: 27: 50$ & $\begin{array}{l}13: 40: 5 \\
4\end{array}$ & 31 & 1 & 0 & & S & \\
\hline 44464 & S9047UP & KMTU8210275 & $\begin{array}{l}\text { EX } \\
P\end{array}$ & 40 & $1: 58: 12$ & $2: 15: 46$ & 31 & 1 & 0 & & S & \\
\hline
\end{tabular}

Note $: \operatorname{Exp}=$ Export, $\operatorname{Imp}=$ Import, $\mathrm{TM}=$ Time Movement, $\mathrm{DM}=$ Detail Movement,

Table 3. Result of data analysis in Phase 2

\begin{tabular}{lrrrrrr}
\hline & \multicolumn{2}{c}{ JAN } & & \multicolumn{2}{c}{ TOTAL } \\
\cline { 2 - 3 } \cline { 7 - 8 } & $\mathbf{2 0 1 5}$ & $\mathbf{2 0 1 6}$ & & $\mathbf{2 0 1 5}$ & $\mathbf{2 0 1 6}$ \\
\hline Truck operation & 22,157 & 20,099 & & $\ldots$ & 266,313 & 246,203 \\
Export / Pick up & 24,307 & 24,580 & & $\ldots$ & 312,650 & 290,178 \\
Import / Delivery & $\mathbf{4 6 , 4 6 4}$ & $\mathbf{4 4 , 6 7 9}$ & $\ldots$ & $\mathbf{5 7 8 , 9 6 3}$ & $\mathbf{5 3 6 , 3 8 1}$ \\
\hline TOTAL & 28,620 & 27,494 & $\ldots$ & 367,869 & 344,897 \\
\hline Truck Movement & 6,961 & 6,057 & $\ldots$ & 82,612 & 72,673 \\
TMOC & & & & & \\
TMMTOC & & & & &
\end{tabular}


Table 3, Cont. Result of data analysis in Phase 2

\begin{tabular}{|c|c|c|c|c|c|}
\hline TOTAL & 35,581 & 33,551 & ... & 450,481 & 417,570 \\
\hline $\begin{array}{l}\text { Amount of Containers } \\
\text { Container TM-OC }\end{array}$ & 28,620 & 27,494 & $\ldots$ & 367,869 & 344,897 \\
\hline Container TM-MTOC & 17,844 & 17,185 & $\ldots$ & 211,094 & 191,108 \\
\hline TOTAL & 46,464 & 44,679 & ... & 578,963 & 536,005 \\
\hline $\begin{array}{l}\text { Maximum Containers } \\
\text { MAX Container/ Day }\end{array}$ & 19 & 14 & & & \\
\hline Export (E)/ Import (I) & $\mathrm{E}$ & $\mathrm{E}$ & & & \\
\hline Sum of Truck/ month & 10,852 & 10,512 & ... & 17,143 & 16,413 \\
\hline \multicolumn{6}{|c|}{ Truck Movement Pattern } \\
\hline SPD Export & 1,086 & 426 & & 13,572 & 6,129 \\
\hline SPD Import & 1,086 & 426 & & 13,572 & 6,129 \\
\hline Kombo Export 1 & 3,163 & 3,473 & & 33,719 & 30,495 \\
\hline Kombo Export 2 & 3,045 & 3,407 & & 31,889 & 30,012 \\
\hline Kombo Import 1 & 1,195 & 1,144 & & 16,001 & 18,829 \\
\hline Kombo Import 2 & 1,231 & 1,167 & & 16,676 & 19,308 \\
\hline Return Export & 9 & 16 & & 96 & 369 \\
\hline Return Import & 26 & 12 & & 376 & 633 \\
\hline Single & 35,623 & 34,608 & & 453,062 & 424,101 \\
\hline TOTAL & 46,464 & 44,679 & & 578,963 & 536,005 \\
\hline
\end{tabular}

\section{Discussion and Results}

\section{Result}

\section{The analysis result of phase I}

On the slice of data contained in the sheet "source" in Table 2. The movement pattern of container trucks consisting of standard movement (single \& return), combo and simultaneous pickup \& delivery (SPD).

The standard movement pattern (single), shown by truck no. A9109UA with pick up the container OOLU9437895 for export, container size of 40 " (feet), then enter the terminal on the 1st of 2:50:27 and out at 3:55:21, enter the gate with container (1) and exit the gate without the container (0). The standard movement pattern (return), the truck with no. B9001UEK. Combo movement pattern (import / delivery), truck with the same no. B9001UEK delivering two containers OOLU1868330 \& OOLU1451623 (20 feet) in one 
trip. Simultaneous pickup and delivery (SPD) movement pattern, truck no B9012SOK pick up container OOLU8162812 (1) and deliver container OOLU7399224 (1), time movement required is 0: 03:17 for the truck exit and then back to the terminal. Combination movement combos and SPD is the most effective movement, this can be seen on the 13th where a truck with no. B9068AX can carry four containers CAXU6541840, TGHU3101780, CRXU1554279 and TEMU4257409 with time movement 0:00:17.

\section{The analysis results of phase II}

The result analysis In Table 3, for truck movement in 2015 divided into trucks pick up containers to terminals $46 \%$ and trucks delivering containers from the terminal $54 \%$.

The number of TM-OC is 367,869 or $63.5 \%$ of the total number of containers in 2015. The number of TM-MTOC in 2015 as many as 211,094 can be brought by 82,612

In January 2015 The maximum amount is a truck was able to pick up 19 containers.

SPD and Combo (combinations) are the most efficient movement patterns and an ideal model. Trucks that do this activity in 2015 by $0.4 \%$ and in 2016 by $0.18 \%$ of total containers. The combination of these movements can be seen in January 2015 where there is a difference between Combo Export1 3.163 while Combo Export2 3,045 there is a difference of 118 containers of Combo Export, the difference of the number of containers indicates that the truck picking up combo containers to terminal and then truck delivering the container from the terminal.

SPD in January 2015 recorded 1,086 movements. Combo Export/Import in 2015 produce 98,285 containers (17\% of total containers). Standard movement (single / return) in 2015 is $78.3 \%$ (453,062 containers). The Return is a single-motion truck but returns to the terminal within the same day to re-engage in TPK Koja. 


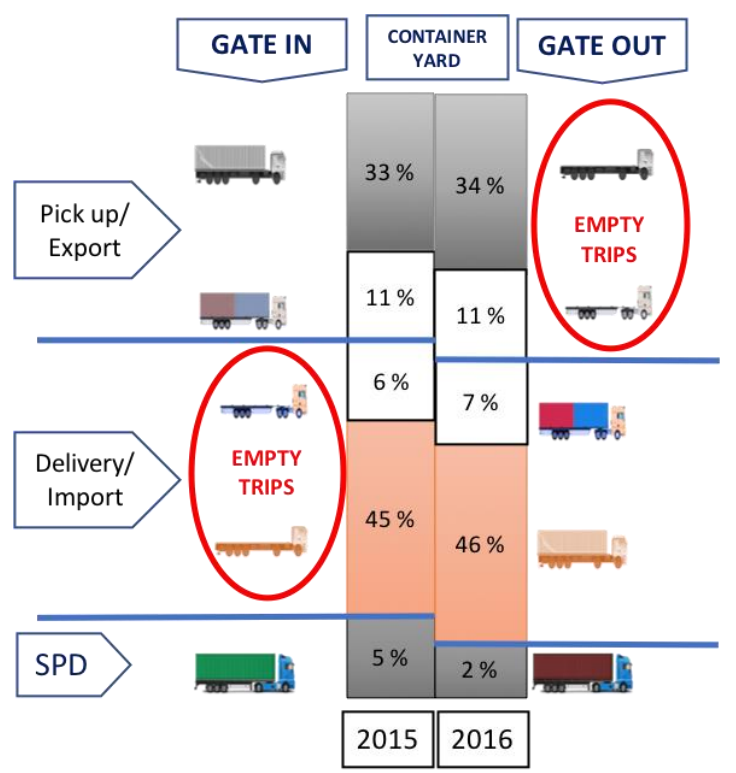

Figure 1. Empty trips container truck

\section{The empty trip}

In Figure 1 is an illustration of container trucks without carrying any containers. The truck requires two movements to pick up or deliver the container, enter the terminal and exit the terminal.

Trucks to TPK Koja do the empty trips in 2015 by $48 \%$ (45\% single and $3 \%$ combo) and empty trips from the terminal 38.5\%. Whereas for market share throughput of TPK Koja to the Port of Tanjung Priok in 2015 and 2016 is $17.2 \%$ and $13.9 \%$.

Assuming a homogeneous business pattern and based on the interview with the owner of the trucking company it is known that container trucks operating in TPK Koja also operates to all terminals in Tanjung Priok Port. So that trucks are doing the empty trips at Tanjung Priok Port can be calculated. The formula for counting the empty trip in Tanjung Priok is $($ Empty trips Tanjung Priok $=$ Empty trips TPK Koja $/$ Market share TPK Koja). Empty trips Port of Tanjung Priok in 2015 as many as 1.620 .191 (in) -1.299 .528 (out) then in 2016 as many as 1.522 .727 (in) and 1.908.227 (out). 


\section{Discussion}

Based on movement pattern and empty trip, it can be concluded that the potential of congestion at Tanjung Priok Port . The growth of port capacity is expected to increase the growth of containers, it is potentially increasing congestion in the port area. Reducing the congestion should be focused on the regulation, implementing the efficient movement, creating an IT-bases scheduling system and collaborating port stakeholders to optimize existing facilities.

Regulation, the movements pattern of export and import combo that already prohibited by government regulation is in fact still to be found. The reason for the truck carrying a combo container is the efficiency of container truck trip and transportation cost savings. Truck owners are faced with a tough choice, if the truck carries only one container of 20 " then the shipper/consignee is only willing to pay half of the transportation cost. The government needs to make adjustments to the rules in order to be implemented properly. Combo container with full/ empty for imports and combo containers with empty for export, should be legalized by government regulations. The existence of combo practice today is feared to be a chance of illegal costs in the port.

Efficient movement, the movement pattern of SPD is a very effective pattern of movement and does not violate government regulations. Trucking companies capable of performing this operation are trucking companies that also have logistics business, which has a business license forwarding, have empty container depot and there also have business as an exporter (shipper) or an importer (consignee). With a complete logistics flow, it is very easy for the company to get the export/import container information that can be used to set up a very effective truck movement pattern.

Creating an IT system, optimization of container trucks can be done by creating an IT-based scheduling system where container trucks can perform simultaneous pick up \& delivery (SPD). This best practice has been done by some trucking companies in Tanjung Priok Port, so this can be a 
reference in applying a unique system in accordance with the condition of Tanjung Priok Port. This is important, creating a good system is not a difficult thing but applying a system needs serious efforts and commitment from stakeholders.

Collaboration for optimization, port stakeholders both government and employers need to collaborate to optimize existing facilities, low pollution, high levels of utility, smooth, timely and large economic benefits (Permnehub 49, 2005, Sistranas). This can be realized one of them by optimizing the mode of transport of container trucks.

\section{References}

Danloup N, Mirzabeiki V, Julien D and Mena C. (2015). Reducing transportation greenhouse gas emissions with collaborative distribution: A case study. Management Research Review. 38 (10): 1049-1067.doi 10.1108/MRR-11-2014-0262

Dekker R, Heide SVD, Asperen EV, Ypsilantis P. (2012). A chassis exchange terminal to reduce truck congestion at container terminals. Flex Serv Manuf J. 25 (2013) :528-542. doi 10.1007/s10696-012-9146-3

Giuliano G, O'Brien T. (2007), Reducing port-related truck emission: The terminal gate appointment system at the Ports of Los Angeles and Long Beach. Transportation Research Part D 12: 460 - 473. doi: 10.1016/j.trd.2007.06.004

Islam S, Olsen T, Ahmed MD. (2013). Reengineering the seaport container truck hauling process, Reducing empty slot trips for transport capacity improvement. Business Process Management Journal. 19(5): 752-782.doi 10.1108/BPMJ

Islam S, Olsen T. (2014). Truck-sharing challenges for hinterland trucking companies A case of the empty container truck trips problem . Business Process Management Journal. 20 (2):.290-334. doi 10.1108/BPMJ-032013-0042

Irpan T, Sony I, Sarinah. (2016). Kajian Peningkatan Peranan Transportasi Multimoda Dalam Mewujudkan Visi Logistik Indonesia 2025. Jurnal Manajemen Bisnis Transportasi Dan Logistik, 3 (1) : 69 - 84

Juan AA, Faulin J, Bernabeu EP, Jozefowiez N. (2013). Horizontal cooperation in vehicle routing problem with backhaul and environment criteria. Science Direct, Procedia - Social and Behavioral Sciences. 111 (2014) 1133 - 1141. doi :10.1016/j.sbspro.2014.01.148

Kadarisman M, Yuliantini, Majid SA. (2016). Policy Formulation of Sea Transportation System. Jurnal Manajemen Transportasi \& Logistik (JMTranslog). 3 (2): 161 - 183. ISSN 2355-4721 
Kiani M, Sayareh J, Nooramin S. (2009). A simulation framework for optimizing truck congestions in marine terminals. Journal of Maritime Research. 7 (1): 55-70.

Kopfer HW, Schonberger J, Kopfer H. (2013). Reducing greenhouse gas emissions of a heterogeneous vehicle fleet. Flex Serv Manuf J. 26 (2014) :221-248. doi: 10.1007/s10696-013-9180-9

Lesmini L, Purwanto B. (2016). Ekonomi Maritim \& Sumber Daya Manusia Indonesia. Jurnal Manajemen Bisnis Transportasi Dan Logistik. 2 (3): 372 $-389$

Maloni MJ, Jackson EC. (2007). Stakeholder Contributions to Container Port Capacity: A Survey of Port Authorities: Journal of the Transportation Research. 46(1):23-42.

Mitra S. 2008. A parallel clustering technique for the vehicle routing problem with split deliveries and pickups. Journal of the Operational Research Society. 59 (2008): 1532--1546. doi :10.1057/palgrave.jors.2602500

Nooramin AS, Ahouei VR, Sayareh J. (2011). A Six Sigma framework for marine container terminals. International Journal of Lean Six Sigma. 2(3): 241-253. doi 10.1108/20401461111157196

Nugraha Y, Mujiono, Wahyu D. (2016). Logistic Costs And The Good's Delivery Effectiveness To Book Stores. Jurnal Manajemen Transportasi \& Logistik (JMTranslog). 3 (2): 227 - 243. ISSN 2355-4721

Peetijade C, Bangviwat A. (2012). Empty trucks run reduction in Bangkok area towards sustainable transportation. International Journal of Trade, Economics and Finance. 3 (2,) April 2012

Peraturan Dirjen Perhubungan Laut no 103. (2016). Berat Kotor Petikemas Terverifikasi (verified gross mass of container - VGM).

Peraturan Menteri Perhubungan no 14. (2007). Tentang Kendaraan Pengangkut Petikemas di Jalan

Peraturan Menteri Perhubungan no 49 tahun (2005). Tentang Sistem Transportasi Nasional (Sistranas)

PT Pelabuhan Indonesia II (Indonesia Port Corporation) (2015), Annual report.

Rafi S, Purwanto B. (2016). Dwelling Time Management (Antara Harapan Dan Kenyataan Di Indonesia). Jurnal Manajemen Bisnis Transportasi Dan Logistik. 2 (2): 220 -228

Regan AC, Golob TF. (1999). Trucking industry perceptions of congestion problems and potential solutions in maritime intermodal operations in California. Working paper, Institute of Transportation Studies University of California Irvine. 34 (1999): 587-605 .

Russ BF, Yamada T, Castro JT, Yasukawa H. (2005). Optimising the design of multimodal freight transport network in Indonesia. Journal of the Eastern Asia Society for Transportation Studies. 6 (2005): 2894 - 2907. Undang - Undang Republik Indonesia no 17. (2008). Tentang Pelayaran. 
Appendix

Flow chart data analysis

Figure 2. Flow chart data analysis

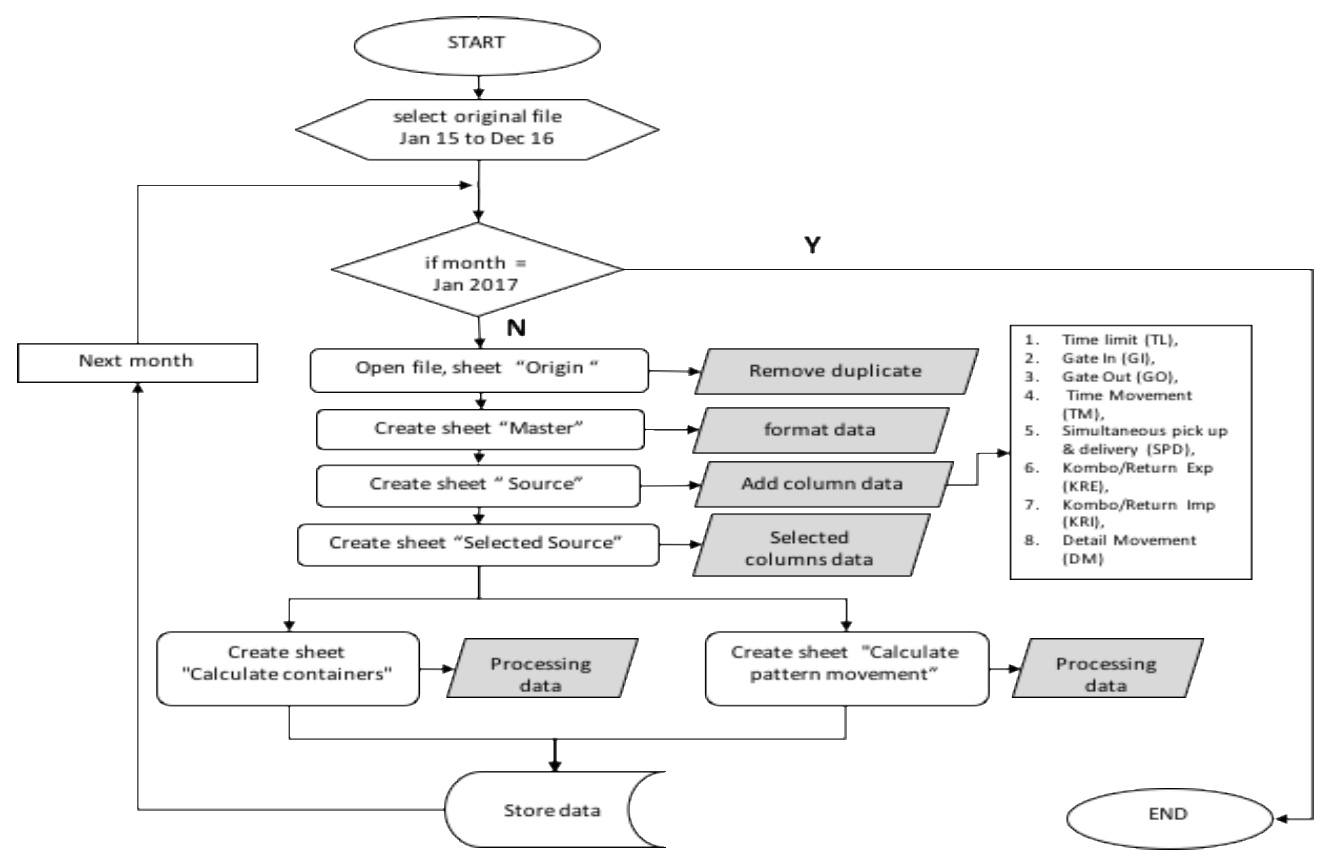

The following series of processes are performed to create a data analysis that is:

\section{Phase 1}

Cleaning data, data cleaning is done to remove duplicates of existing data, with large amounts of data is essential to ensure that there is no duplicate data.

Formatting data, the data needs to be placed in a new sheet and named "master", all the data in the "origin" sheet is copied and paste the link to the "master" sheet. Then format the Truck in (TI) and Truck Out (TO) columns as time. Formatting in Date field (DN) with data format as date, last add column data to calculate Turn Roundtime Truck (TRT). Data format is done because at the time of downloading data, format used is txt.

Adding Data Column, raw data downloaded from the terminal operating system (TOS) is not enough to process the next data analysis, so the additional data is added into the new data columns. These new data columns are created with a formula in the excel application based on the existing raw data. Initial 
step is by inserting to create new sheet and named "source", then move file (copy \& paste link) from all data in sheet "Master".

The next process adds new data columns with the following data formulas:

Time Limit (TL) filled with time format 00:01:00 (one minute) and 1:00:00 (one hour). Time limits will be used in identifying less than one minute combo activity patterns, SPD activity patterns of one minute and one hour and Return activity below the hour time limit, in addition to the Single activity pattern.

Gate In (GI) and Gate Out (GO) to construct a binary scale, where indicating the number "1" means the truck passes the gate with the container and the " 0 " truck passes the gate without carrying the container. This scale is needed to identify how many trucks are unloaded "0" (empty trips).

Time Movement (TM) to determine the difference in movement of container trucks entering / exiting the terminal more than once or container trucks that enter / exit with carrying more than one load simultaneously.

Simultaneous pick up \& delivery (SPD), is a pattern of movement that has been done by a small truck at the Koja Container Terminal (TPK Koja). The finished truck carrying (pick up) the export container then simultaneously delivering the imported container to the factory. To be able to know the pattern of this movement in the sequence of existing data, it takes a formula in excel to identify it. Truck In "1" and truck out "1" in the span of time between one minute and one hour.

Combo \& Return, Combo is a term that is commonly used in Tanjung Priok Port to simplify the mention of truck activity patterns that carry two 20 feet containers in one chassis. Although the Ministry of Transportation already issued the rules, which prohibits the pattern of this activity, but in practice not so. One of the case is when carrying empty containers (empty containers). Based on the raw data available, Combo can be known by: one truck carrying two different containers with the size of 20 feet at the time difference between one container with other containers less than a minute. The Return is a truck activity pattern that returns to perform the same activity within a span of between one minute and one hour. Combo \& Return is made in two different 
columns, namely: Combo export (CE) and Return export (RE) and Combo import ( CI) \& Return import (RI).

Movement Details (DM), new columns containing the entire movement pattern of container trucks (SPD, CE, CI). This column also adds a Single movement pattern that is not included in the previous movement pattern category. In this column also details each pattern of activities, for example: SPD is divided into SPD Exp and SPD Imp, CE into Combo Exp 1, Combo Exp2 and return. This is done to facilitate the identification of all patterns of activity and identification if trucks are found combining combo and SPD patterns in one activity.

Sorting data, sorting all the data contained in the sheet "source" becomes very important. The activity pattern already written in the excel formula will not work if the data is not arranged in sequence based on date, no truck and serial number of transactions in the gate in accordance with its arrival. The date sequence is required to separate daily activities, no truck sequences to identify trucks carrying or delivering containers more than once and ordering them to sort the container no later according to the order of arrival.

\section{Phase 2}

Selecting data, is by selecting certain data columns used for further analysis process. This step is done by inserting a new sheet and named "Selected Source". In this sheet contains data that moved sheet "Source" by copy and paste the link.

Count the number of trucks, by using the pivot table of "Selected Source". This is done by placing the cursor on one of the data then click insert select pivot table to select data to be analyzed with table / range of all data then select new worksheet next named "Calculate Container". In Pivot Table Builder in columns select Data Date Number (DN) and Stat (CS), to rows select Truck No (TN) data and to value select Container ID (CI). From this calculation process can be known from row data how many trucks that do pick up / delivery activities in the month. The number of containers can be seen in each column indicating the number of containers each day brought by each truck. 
Counting the number of containers carried, this process is carried out to find out the total number of export pickup and container carried by the truck daily. Then calculated how the maximum number of containers that can be carried by a container truck.

Counting TM-OC \& TM-MTOC, One truck unit can carry large quantities of containers with multiple exits in and out of the terminal. Then calculate the number of trucks that only buy one container each day TM-OC (truck movement only one container) while TM-MTOC (truck movement with more than one container) is the number of trucks capable of carrying more than one container each day or truck that back to the terminal within the same day. The last count is to know how many containers are carried by TM-OC and TM-MTOC.

Calculating the number of patterns of movement of container trucks, movement pattern in pickup and delivery process in TPK Koja generally is divided into three parts: Standard movement (single \& return), Combo movement and Simultaneous pickup \& delivery (SPD). The calculation process is to know the number of trucks that perform the pattern of movement performed. The series of analytical processes performed with the excel formula in January 2015 will be the template for making the analysis in the following months. Data analysis will be completed by December 2016 